\title{
Pantheistic versus Participatory Christologies: A Critical Analysis of Richard Rohr's Universal Christ in Light of Thomas Aquinas's Commentary on John
}

\author{
Michael A. Dauphinais (Ave Maria University)
}

\begin{abstract}
This essay will present Richard Rohr's central claims about Jesus Christ and the presence of God in creation and then consider them in light of Aquinas's teachings with particular attention to his Commentary on John. This essay attempts to show that Rohr's claims are incomplete and ultimately misguided and that Aquinas's participatory account of creation and the Incarnation allows him to cultivate an awareness of God's presence in all of creation while also maintaining the salvific uniqueness of the Incarnation.
\end{abstract}

EJSTA 39 (2021)

DOI:

10.2478/ejsta-2021-0001

Article history:

Received: 1.8 .2020

Accepted: 7.10.2020

Available online:

11.11.2021

\section{sciendo}

Keywords

Thomas Aquinas $\bullet$ Richard Rohr $\bullet$ Christology $\bullet$ incarnation $\bullet$ pantheism

Richard Rohr's The Universal Christ: How a Forgotten Reality Can Change Everything We See, Hope for, and Believe articulates a creation-centered approach to Christology. ${ }^{1}$ Rohr is a Franciscan spiritual teacher who has reportedly helped a number of people discover greater integration and peace in their earthly lives. He is sometimes known among circles of people who are-and those who work with those who arerecovering from addictions. ${ }^{2}$ He has authored numerous books on spirituality and Christian mysticism and communicates in an accessible and engaging manner. The book in question, The Universal Christ, has become a New York Times bestseller and includes blurbs from celebrity figures such as Melinda Gates and Bono. Rohr may appear an odd selection for the present analysis because he is a popular author who writes and speaks outside the typical context of university or seminary education.

\footnotetext{
${ }^{1}$ R. Rohr, The Universal Christ: How a Forgotten Reality Can Change Everything We See, Hope for, and Believe, (New York: Convergent Press, 2019).

2 R. Rohr, Breathing Under Water: Spirituality and the Twelve Steps, (Franciscan Media, 2011).
} 
Rohr's book expresses a problematic trend to view the creation in incarnational terms and likewise to see the incarnation in terms of creation. ${ }^{3}$ The doctrine of the Incarnation thus tells us about the true meaning of creation rather than revealing something specific about Jesus Christ. According to this view, all of creation is filled with God's presence and is evolving to higher unity with God. This way of interpreting the Incarnation focuses on all of creation rather than focusing on Jesus Christ and his Church. As such I am describing it only slightly provocatively as a pantheistic Christology and will contrast it to the participatory Christology of Thomas Aquinas. This essay will present Richard Rohr's central claims about Jesus Christ and the presence of God in creation and then consider them in light of Aquinas's teachings with particular attention to his Commentary on John. ${ }^{4}$ This essay attempts to show that Rohr's claims are incomplete and ultimately misguided and that Aquinas's participatory account of creation and the Incarnation allows him to cultivate an awareness of God's presence in all of creation while also maintaining the salvific uniqueness of the Incarnation.

\section{Rohr's Reinterpretation of Christianity: Creation as Incarnation}

The presentation of Rohr's teaching will proceed following the two parts of his book: first, the rediscovery of the universal Christ and the first incarnation of creation; and second, the way in which the historical Jesus reveals the universal patterns of this first incarnation. As is evident in the subtitle of the book, Rohr reinterprets the Christian

\footnotetext{
${ }^{3}$ For instance, in Incarnation: A New Evolutionary Threshold, (Maryknoll, NY: Orbis Books, 2017), Diarmuid O'Murchu presents creation itself as an incarnation: "This is a book about Incarnation, which, for the moment, I understanding to mean God's embodiment in creation as experienced and named by human beings" (44, italics original unless otherwise noted). O'Murchu writes, "Without body, however, the Spirit goes nowhere; it is in and through bodies that spirit becomes grounded and generic at every level of creation's evolution" (62). In a similar vein, Ilia Delio, O.S.F., in her The Emergent Christ: Exploring the Meaning of Catholic in an Evolutionary Universe (Maryknoll, NY: Orbis Books, 2011), presents creation as an incarnation with an evolutionary thrust: "Every act of evolving nature is the self-expression of God, since the very act of nature's transcendence is the energy of divine love. God unfolds in the details of nature; thus, evolution is not only of God but is God incarnate" (51). Delio writes, "These emerging Christ fields are new basins of attraction, transcending institutional religion, signaling a new religious consciousness, a new God-centeredness that inspires and empowers co-creativity for a new humanity and a new earth" (145). According to Delio, evolutionary creation is the incarnation, ever moving forward and more fully incarnating divine love.

${ }^{4}$ For a critical review of Fr. Rohr's book, see M. McClymond, "'Everything Is Christ" - and Other Muddled Messages from Richard Rohr', The Gospel Coalition, published September 16, 2019 (https://www.thegospelcoalition.org/reviews/universal-christ-richard-rohr/, accessed January 17, 2020). For an adulatory review, see C. Falsani, 'In new book, Richard Rohr says the "universal Christ" changes everything', National Catholic Reporter, published April 1, 2019 (https://www.ncronline.org/news/spirituality/new-book-richard-rohr-says-universal-christ-changeseverything, accessed January 17, 2020). For another sympathetic portrayal, see E. Griswold, 'Richard Rohr Reorders the Universe', The New Yorker, published February, 2, 2020 (https://www.newyorker.com/news/onreligion/richard-rohr-reorders-the-universe, accessed February 12, 2020).
} 
understanding of Jesus Christ in an attempt to unveil a new key to our experience of the world and of one another as the incarnate presence of God. ${ }^{5}$

Rohr claims that Christianity has focused too heavily on the particular instance of the historical Jesus and so has missed the real point of Christianity: the revelation of the universal Christ as always already present everywhere and in everything. This may be seen in two questions he articulates in his introduction: "What if Christ is a name for the transcendent within every 'thing' in the universe?" and "what if Christ is another name for everything - in its fullness?" 6 Rohr shifts the attention of the reader to the creation of the cosmos as the "first Incarnation". He writes, "The incarnation, then, is not only 'God becoming Jesus'". Instead, all of creation is the incarnation or the "enfleshment of spirit": "Everything visible, without exception, is the outpouring of God". 7 Gesturing at the pre-existent and cosmic visions of Christ as articulated in John 1:1-18, Colossians 1:15-20, and Ephesians 1:3-14, Rohr claims that this cosmic Christ has been overlooked by a focus on the historical Jesus in his particularity. ${ }^{8}$ He summarizes the supposed error, "in Christianity, we have made the mistake of limiting the Creator's presence with just one human manifestation, Jesus". ${ }^{9}$ Rohr wishes, instead, for the reader to see God's presence in all creation. He writes, "God loves things by becoming them". ${ }^{10}$

The shift to seeing creation itself as the incarnation of God, for Rohr, opens up a new way of seeing God's presence in the world. He wishes the reader to find a panhuman spirituality: "If all of this is true, we have a theological basis for a very natural religion that includes everybody". ${ }^{11}$ Rohr moves from the particular Jesus to the universal Christ supposedly to help everyone to discover the presence of God already in the world, in their neighbors, and in themselves.

Rohr invites his readers to adopt this new way of seeing the world opened up by Jesus, one of inclusivity rather than exclusivity. He writes, "In Jesus Christ, God's own broad, deep, and all-inclusive worldview is made available to us". ${ }^{12}$ Rohr alleges that Christianity has missed this change of perspective offered to us by Jesus Christ and so fell into exclusivity and, worst, of all used Jesus as the principle of exclusion. He writes, "too often, we have substituted the messenger for the message". Rohr says

\footnotetext{
${ }^{5}$ The subtitle of his book reads, "How a Forgotten Reality Can Change Everything We See, Hope For, and Believe".

${ }^{6}$ Rohr, The Universal Christ, 5.

${ }^{7}$ Rohr, 12-13.

${ }^{8}$ Rohr, 17. "Numerous Scriptures make it very clear that Christ has existed 'from the beginning' (John 1:118, Colossians 1:15-20, and Ephesians 1:3-14 being primary sources), so the Christ cannot be coterminous with Jesus. But by attaching the word 'Christ' to Jesus as if it were his last name, instead of means by which God's presence has enchanted all matter throughout all of history, Christians got pretty sloppy in their thinking. Our faith became a competitive theology with various parochial theories of salvation, instead of a universal cosmology inside of which all can live with an inherent dignity".

${ }^{9}$ Rohr, 16. There's a deep irony here that this contrast presumes a dualistic view of God-as-present-in-Jesus vs. God-as-present-in-all-creation.

${ }^{10}$ Rohr, 16, 20.

${ }^{11}$ Rohr, 21.

${ }^{12}$ Rohr, 32.
} 
that Christians have been too concerned with worshipping Jesus rather than "actually following what he taught-and he did ask us several times to follow him, and never once to worship him". ${ }^{13}$ Per Rohr, the goal of the Christian is not to see the historical Jesus but to see the universal Christ: "A mature Christian sees Christ in everything and everyone else". ${ }^{14}$ Rohr asserts that this divine omnipresence necessitates radical inclusivity: "The only thing [Jesus] excluded was exclusion itself". ${ }^{15}$ Rohr asserts that "we need both a Jesus and a Christ" in his effort to keep them divided from each other. Jesus remains a moment on the journey to Christ. He writes, "When your isolated ' $\mathrm{I}$ ' turns into a connected 'we,' you have moved from Jesus to Christ". ${ }^{16}$ Moving from Jesus to Christ allows Rohr's readers to see creation as the primary incarnation of the universal Christ and so to an all-inclusive vision of creation.

In order to move from the historical Jesus to the universal Christ, Rohr wants to move away from the Christ of the creeds. Rohr explains, the creeds "reaffirm a static and unchanging universe, and a God who is quite remote from almost everything we care about each day. ... The Christ of these creeds is not tethered to earth-to a real, historical, flesh-and-blood Jesus of Nazareth" ${ }^{17}$ Per Rohr, the historical Jesus witnesses to the universal Christ, to the universal presence of God in creation, to the idea that all creation is incarnation. Rohr describes the turn from the creedal Christ to the universal Christ as a paradigm shift. Just as Christianity has been a "two-thousand-year-old paradigm shift from Judaism", Rohr now proposes another paradigm shift from Christianity as a particular religion to Christianity as an awareness of the universal Christ. He asserts the fruit that he hopes this shift will bear: "Jesus can hold together one group or religion. Christ can hold together everything". ${ }^{18}$ No longer is the Incarnation something that only happened in Jesus or is the Incarnate Word only worshipped by Christians, now everything is Incarnation. ${ }^{19}$

\footnotetext{
${ }^{13} \mathrm{Rohr}$, 32. This approach seems squarely within the expression oft-attributed to Unitarian theology that Christianity should be "the religion of Jesus, not the religion about Jesus". While Rohr wants to move from Jesus to Christ, the influential Adolf von Harnack moved from Christ to Jesus in his influential lectures and book Das Wesen des Christentums or What is Christianity? Von Harnack moved away from Christ to Jesus in order to move "away from dogma, onward to love", something distinctly observable in Rohr. Joseph Ratzinger summarizes von Harnack's approach, "the watchword is obvious: back past the preached Christ, the object of divisive belief, to the preaching Jesus, back to the summons to the unifying power of love under the one Father with all our brothers" (199, italics added) in J. Ratzinger, Introduction to Christianity (San Francisco, CA: Ignatius Press, 2004), translated by J. R. Foster and Michael J. Miller.

14 Rohr, 33.

15 Rohr, 34.

${ }^{16}$ Rohr, 37.

17 Rohr, 104-105.

18 Rohr, 47.

${ }^{19}$ Rohr attempts to defend his claim against those who might allege that this view is pantheistic: "Paul merely took incarnationalism to its universal and logical conclusions. We see that in his bold exclamation 'There is only Christ. He is everything and he is in everything' (Col 3:11). If I were to write that today, people would call me a pantheist (the universe is God), whereas I am really a panentheist (God lies within all things, but also transcends them), exactly like both Jesus and Paul" (43).
} 
In presenting creation as incarnation, Rohr deploys a foundational dichotomy between dualism and non-dualism. He affirms that dualism sees God as separate from his creation, where as non-dualism sees God within all creation. Rohr is not clear about when exactly dualism entered into and corrupted the original non-dualistic Christian message. He asserts variously that dualism came in with the rise of the Christian emperors and the early councils and creeds, with the Reformation and the Enlightenment, or even that it has bound the first two thousand years of Christianity. ${ }^{20}$ Likewise, he identifies non-dualistic or holistic Christianity at times with Paul's conception of the cosmic Christ, the Eastern Church, mystics, or the third millennium we have just entered. ${ }^{21}$ At other points, he contrasts dualistic and non-dualistic ways of thinking as rational thinking or the "binary mind" versus a "contemplative way of knowing". ${ }^{22}$ Moving from dualism to non-dualism thus moves from a particular and exclusive emphasis on Jesus as the object of creedal faith to a universal and inclusive emphasis on the universal Christ without creeds. By way of example, Rohr exhorts his reader, "We kept ourselves so busy trying to process the idea of Jesus as the personal incarnation of God, and a God that an empire (East or West!) could make use of, that we had little time or readiness to universalize that message to all 'flesh' (John 1:14), much less of all creation (Romans 8:18-23)" ${ }^{23}$ Rohr here reinterprets the incarnation, "the Word became flesh" (Jn 1:14), from a dualistic claim about Jesus to a non-dualistic truth about all creation.

After presenting creation as the incarnation of the universal Christ, Rohr uses this theme to reinterpret the mysteries of Jesus' life, death, and resurrection. Rather than seeing Jesus as unique (dualistic), Rohr presents Jesus as unveiling patterns present in all creation (non-dualistic). In the second part of his book, Rohr goes through Jesus' story to show how it witness to the universal Christ of creation. For instance, the Eucharist, the crucifixion, and the resurrection show the reader the deeper reality of all creation.

As presented by Rohr, the Eucharist reveals God's presence in all creation. He writes, "Seeing [the Eucharist] as a miracle is not really the message at all", instead the Eucharist is "the pattern of everything - and not just this thing". ${ }^{24}$ To focus on the unique presence of God in the Eucharist, to see him in the Eucharist and not elsewhere, is to

\footnotetext{
${ }^{20}$ Rohr writes, "To legitimate our new religion in the Roman Empire, Christians felt that we have to prove that Jesus was independently divine", then refers to the Councils of Nicaea (325) and Chalcedon (451) and concludes, "we were more interested in the superiority of our own tribe, group, or nation than we were in the wholeness of creation. Our view of reality was largely imperial, patriarchal, and dualistic" (45).

${ }^{21}$ Rohr writes, "We must point out that these hidden but fully corporate understandings in Paul, since most Western dualistic minds have been preconditioned to read his letters in a purely anthropocentric and individualistic way" (168); "In the fourteenth century, the book's author would've enjoyed the last remnants of mystical holism before it was taken away with the dualistic-but also necessary-ravages of the Reformation and the Enlightenment" (163);

${ }^{22}$ Rohr, 204-205.

${ }^{23}$ Rohr, 204.

${ }^{24}$ Rohr, 134.
} 
remain in dualistic thinking. The point of the Eucharist, instead, is that it is not unique, "not just this thing", but common, "the pattern of everything". Rohr draws the conclusion, "The universe is the Body of God, both in its essence and in its suffering". ${ }^{25}$ The Eucharist, according to Rohr, not only allows us to see the universe as the essence of God, but allows God to see in a new way as well: "We are not just humans having a God experience. The Eucharist tells us that, in some mysterious way, we are God having a human experience!"26 As he puts it, "It is all one continuum of Incarnation". ${ }^{27}$ Rohr's language here of "one continuum" expresses his commitment to embrace a non-dualism. By discovering the universal Christ, we discover that creation itself and everything in creation is always and already the Incarnation of God. Just as everything is incarnation, so everything is Eucharist.

Rohr likewise approaches the crucifixion as illuminating a universal pattern of creation. To accomplish this holistic and universal view, he rejects what he terms the "penal substitutionary atonement theory" and the dualistic "quid pro quo" it presupposes and engenders. Due to the dualistic understanding of the Cross, "Salvation became a one-time transactional affair between Jesus and his Father, instead of an ongoing transformational lesson for the human soul and for all of history". ${ }^{28}$ The non-dualistic approach opens up the relevance of the Cross. He writes, "The cross is not just a singular event. It's a statement from God that reality has a cruciform pattern". ${ }^{29}$ Just as everything is incarnation, so everything is crucifixion.

According to Rohr, Jesus' resurrection similarly exemplifies the evolutionary movement of all creation. The resurrection announces the universal Christ to be the alpha and the omega of the evolving cosmos. Rejecting what he describes as an individualistic or "privatized salvation", Rohr says that God is "saving and redeeming the Whole ... in [the] Cosmic Sweep of Divine love". ${ }^{30}$ From this view of God's universal salvation, Rohr asks us to shift our view of the resurrection, again from a dualistic to a non-dualistic viewpoint: "from a one-time miracle in the life of Jesus that asks for assent and belief, to a pattern of creation that has always been true". ${ }^{31}$ Rohr writes, "Resurrection and renewal are, in fact, the universal pattern of everything. ... Every time you take in a breath, you are repeating the pattern of spirit taking on matter, and thus repeating the first creation of Adam.... You are an incarnation, like Christ, of matter and spirit operating as one". ${ }^{32}$ Just as everything is incarnation, so everything is resurrection.

\footnotetext{
${ }^{25}$ Rohr, 134.

26 Rohr, 137.

27 Rohr, 138.

28 Rohr, 141.

29 Rohr, 147.

${ }^{30}$ Rohr, 167. Rohr avers, "The true Gospel democratizes the world. We are all saved in spite of our mistakes and in spite of ourselves. We are all caught up in the cosmic sweep of Divine grace and mercy" (166).

${ }^{31}$ Rohr, 169.

${ }^{32}$ Rohr, 99.
} 
Here we turn to a brief response to Rohr's central claims. Rohr constantly reminds his reader to learn to see the universal Christ-the presence of God-in everything and everywhere. Employing memorable turns of phrase, he connects Christian teachings to the everyday, ordinary, and unavoidable experiences of human existence. To be human, to be created, is always and already to be in the presence of God. And, yet, Rohr's reformulation of the Christian life and faith overlooks the unique and efficacious reality of the Incarnation.

When Rohr reinterprets the creation as incarnation, he flattens out reality in a way that distorts the Christian message. No longer distinct, the Creator and creation dissolve into one another. No longer distinct, Jesus and the rest of humanity dissolve into one another. In Rohr's re-envisioning, everything is incarnation; everything is eucharist; everything is crucifixion; everything is resurrection. Although it is true that everything is filled with the divine presence, God is not present in everything in the same manner. By undermining distinctions among modes of divine presence, something that he views as dualistic, Rohr affirms a non-dualistic, flattened sense of the presence of God, in the rocks, in the animals, in human beings, in Jesus Christ, and thus inevitably in God himself. All such presences are "all one continuum of incarnation". Such a view constitutes and exemplifies a contemporary problem in Christology.

Aquinas's Commentary on the Prologue of John: Incarnation, Creation, and Participation

The prologue to the Gospel of John offers an excellent place to consider how the Incarnation is related to the creation. John 1:1 echoes Genesis 1:1, "In the beginning..." and so retells the story of creation now in light of the Incarnation. In the first eighteen verses, we witness affirmations of distinct modes of the divine presence: in the Word of God himself (Jn 1:1-2); in all creation made through the Word (Jn 1:3); in all rational creatures who share in the light of the Word (Jn 1:4); in those who become children of God (Jn 1:12-13); and in Jesus Christ, the Word became flesh (Jn 1:14). How are we to receive such a powerful revelation of God's presence in creation and in the Incarnation?

Aquinas uses the metaphysics of participation to offer a more faithful account of creation and the Incarnation than available to Rohr's limited opposition of dualistic and non-dualistic ways of thinking about God. Dualism and non-dualism both occur within one plane of reality: either-or versus both-and; particular versus universal; transactional versus transformational; the personal incarnation of Jesus or the universal incarnation of the Christ. Participation offers a more adequate response to reality and so to the biblical revelation. It rejects both dualism and non-dualism, while also recognizing the partial truth of each approach. Dualism rightly affirms that the Word is uniquely present in Jesus of Nazareth; non-dualism rightly affirms the Word is also present in each human being. Dualism incorrectly presupposes a God separate 
from the world; non-dualism incorrectly presupposes a God at one with the world. A participatory view of reality allows for a primacy and uniqueness to God's existence while at the same time affirming how God is present in all of creation in various ways.

What then is Aquinas's teaching on participation? To begin, we might approach participation as simply a general way of considering the various ways in which somethings imitate or share in other things. Moving on to greater precision, Aquinas describes participation as follows: "when something receives in particular fashion that which belongs to another in universal (or total) fashion, the former is said to participate in the latter". ${ }^{33}$ Aquinas goes on to distinguish three ways in which things might receive particular aspects from something more universal. First, dogs participate in the wider notion of what it means to be an animal. So also any particular dog participates in the wider notion of what it means to be a dog. Second, a red dog participates in the wider notion of redness. Also, the material components of the dog do not exist on their own but participate in the living dog. Third, effects participate in their causes, such as when a lake warms up in the summer sunshine, the lake's warmth may said to participate in the warmth of the sun. ${ }^{34}$ In each of these ways, Aquinas shows how particular things may be said to participate more universal things.

This essay focuses on Aquinas's third of use of participation described abovenamely, how effects participate in their causes-since this is his preferred mode describing creation's relationship to the Creator. Aquinas offers a helpful summary of creation through the lens of participation in his Summa Theologiae, I, q. 44, a. 1. To begin he cites Paul's doxology in Romans about the presence of God, "of Him, and by Him, and in Him are all things" (Rom 11:36). Aquinas then continues,

"every being in any way existing is from God. For whatever is found in anything by participation (per participationem), must be caused in it by that to which it belongs essentially. ... Therefore all beings apart from God are not their own being, but are beings by participation. Therefore it must be that all things which are diversified by the diverse participation of being, so as to be more or less perfect, are caused by one First Being, Who possesses being most perfectly". ${ }^{35}$

Used in this manner, participation becomes the predominate language by which Aquinas articulates the doctrine of creation. Participation shows how the creation is distinct from the Creator. Participation also show that the creation is not wholly

\footnotetext{
${ }^{33}$ Commentary on the De Hebdomadibus, lect. 2, Leon. 50.271:71-73, as cited and translated by John F. Wippel, The Metaphysical Thought of Thomas Aquinas: From Finite Being to Uncreated Being (Washington, DC: The Catholic University of America Press, 2000), 96.

${ }^{34}$ Although the examples are mine, this threefold presentation follows Aquinas's in his Commentary on the De Hebdomadibus as presented by Wippel, The Metaphysical Though of Thomas Aquinas, 97.

35 Translation by Fr. Laurence Shapcote, O.P., edited by John Mortensen and Enrique Alacaron, as published on the aquinas.cc website.
} 
separable from the Creator since creation depends up the Creator. ${ }^{36}$ God alone possesses existence in its fullness. Created realities only participate in God's perfect existence: "all beings apart from God are not their own being, but are beings by participation". As such, Aquinas not only distinguishes between the Creator and creation but also among countless created beings, which may share in God's being in different manners "so as to be more or less perfect". By speaking of creation as a participation in God, Aquinas thus avoids the dualist/non-dualist dichotomy and accomplishes three necessary insights: first, he maintains radical uniqueness of God's existence; second, he shows that all creatures participate in that existence; and, third, he allows for creatures to participate in God's existence to various degrees.

Let us examine Aquinas's treatment of the prologue of in his Commentary on John and discover how he utilizes his understanding of participation to present the incarnation in relationship to creation. ${ }^{37}$ Following Aquinas's own division of the prologue of John, I will first examine Aquinas's presentation of how creation itself and the rational creature in particular participate in the divine creative Word. ${ }^{38}$ Second, I will examine his presentation of the saving participation of the children of God in the Incarnation of the Word. As we will see, Aquinas helpfully differentiates the reality of creation through the Word of God from the truth that Jesus Christ is the unique Incarnation of the Word. ${ }^{39}$

The Gospel of John begins, "In the beginning was the Word". In commenting upon the meaning of "Word", Aquinas employs the idea of participation. He emphasizes the differences between human words, interior and exterior, and the divine Word. Yet, the difference is not so great to lead to incoherence. Human words, especially in their interior dimension as understandings of reality, share-or participate - in the unique divine Word. Aquinas writes, "although there are many participated truths, there is just one absolute truth, which is truth by its very essence, that is, the divine act of being (ipsum esse divinum); and by this truth all words are words". ${ }^{40}$ Because the Word of God is nothing other than the divine esse itself, the

\footnotetext{
${ }^{36}$ For a recent study that focuses on Aquinas, see A. Davison, Participation in God: A Study in Christian Doctrine and Metaphysics (Cambridge: Cambridge University Press, 2019).

${ }^{37}$ Joseph W. Koterski, S. J., shows how Aquinas's Commentary on John consistently employs a Platonic notion of participation while rejecting the Platonic idea of an independent existence of forms or ideas as well as the neo-Platonic theme of a necessary emanation. This adapted Platonic participation rests on the understanding of the Word of God as co-eternal with the Father and thus equally sharing in God's free creation of the universe. See: J.W. Koterski, 'The Doctrine of Participation in Aquinas's Commentary on John', in: J.M. Hackett, W.E. Murnion, and C.N. Still (eds.), Being and Thought in Aquinas, (Albany, NY: State University of New York Press, 2004), 109-121.

38 See In Io., ch. 1, lect. 1, no. 23, in which Aquinas divides John 1 in two parts with the first five verses manifesting the divinity of Christ and then with the remainder manifesting the incarnation of the Word ${ }^{39}$ See the prologue of the Commentary on John in which Aquinas observes that the Gospel of John was written after the other Gospels in order to affirm the divinity of Christ which became increasing in doubt over time. ${ }^{40}$ In Io., ch. 1, lect. 1, no. 33, emphasis added, translated by Fr. Fabian R. Larcher, O.P. edited and revised by The Aquinas Institute, as published on the aquinas.cc website.
} 
Word is the one truth and thus unlike all of our partial words and incomplete truths as well as that one truth by which all our "words are words".

Here we notice two distinct, yet related, modes of the divine presence. Aquinas describes the first mode of presence as belonging to the Word of God, who is "truth by its very essence, that is, the divine act of being". The divine act of being is appropriate to the divine nature, being completely unlimited by any particular modes of being, unlimited by space and time, ipsum esse subsistens, sheer actuality, sheer and original truth itself. The second mode of divine presence is the way in which the rational creature exists by coming to know and speak a conglomeration of truths, of judgments, and words. ${ }^{41}$ Such a mode of divine presence in the rational creature depends upon the utterly unique and perfect mode of divine presence that is the Word as Creator. ${ }^{42}$

Aquinas continues to comment on the first verse of John to show that the Word fully exists as God. Against the error of Arius, who claimed that the Son was less than the Father, Aquinas argues that the verse "the Word was God" means that the Word is co-eternal and consubstantial with the Father. Against the error of Sabellius, who claimed that the Word was merely another mode of the Father, Aquinas argues that the preposition in "the Word was with God" manifests a distinction of persons so that the Son is equal to the Father and yet not identical to the Father. ${ }^{43}$ Aquinas also rejects the possibility that the affirmation that the "Word was God" might be meant in a metaphorical manner. Contra Arius's claims, the Word possesses the attributes of eternity "he was in the beginning with God" and omnipotence since "all things were created through him". ${ }^{4}$ The Word shares fully in the divinity of the Father because the Word fully possesses the existence and wisdom by which God is God the Creator. Aquinas affirms this truth by distinguishing the Word from his creatures: "the Word is called God absolutely because he is God by his own essence, and not by participation, as men and angels are". ${ }^{45}$ Participation becomes the key way in which Aquinas distinguishes the Word as fully divine from all creatures that receive their being

\footnotetext{
${ }^{41}$ Aquinas distinguishes between the speech of human beings and the noise of animals saying that the latter only communicate passions and feelings. In his Commentary on Aristotle's Politics, he writes, "speech is proper to men, because it is proper to them, as compared to the other animals, to have a knowledge of the good and the bad, the just and the unjust, and other such things that can be signified by speech" (I, I, 37).

${ }^{42}$ Gilles Emery, O.P., writes, "St. Thomas often explains that all natural human knowledge is a participation in the Word", (citing Aquinas, "He shines in everyone's understanding; because whatever light and whatever wisdom exists in men has come to them from participating in the Word", [In Io., ch. 1, lect. 13, no. 246]) in his 'Biblical Exegesis and the Speculative Doctrine of the Trinity in St. Thomas Aquinas's Commentary on John', in M. Dauphinais, M. Levering (eds.), Reading John with St. Thomas Aquinas: Theological Exegesis and Speculative Theology (Washington, DC: The Catholic University of America Press, 2005), 23-61, 37.

${ }^{43}$ In Io., ch. 1, lect. 1, no. 45. See also, "And so, and the Word was with God, indicates: the union of the Word with the Father in nature, according to Basil; their distinction in person, according to Alcuin and Bede; the subsistence of the Word in the divine nature, according to Chrysostom; and the authorship of the Father in relation to the Word, according to Hilary" (no. 51).

${ }^{44}$ In Io., ch. 1, lect. 1, no. 62.

${ }^{45}$ In Io., ch. 1 , lect. 1 , no. 57 , emphasis added.
} 
through the Word. Aquinas writes, "our Lord is saying that he is the source or beginning with regard to all creatures: for whatever is such by essence is the source and the cause of those things which are by participation". ${ }^{46}$ As the Creator, the Word is distinct from-neither separate from nor confused with-his creation because he is creation's source or present cause. ${ }^{47}$

Aquinas employs participation to show how rational creatures arrive at wisdom. Participation thus shapes not only the existence of creatures but also their activities. He writes, "there is one absolute wisdom elevated above all things, that is, the divine wisdom, by participating in which all wise persons are wise. Further, there is one absolute Word, by participating in which all persons having a word are called speakers. Now this is the divine Word which of itself is the Word elevated above all words". 48 The divine truth, the divine wisdom, the divine Word is the fullness of actuality and as such shares itself uniquely with intelligent creatures in their activity of learning truths, gaining wisdom, and speaking words. Moreover, Aquinas describes rational creatures as not only coming to know this or that truth, "but truth itself, which can be manifested and is manifestive to all". ${ }^{49}$ Truth is to be shared, not only in its discrete modes of distinct truths, but truth in itself, as one. ${ }^{50}$

Aquinas further draws upon the idea of participation to discuss the Word as "the light of men" (Jn 1:4). The intellectual vision of rational creature differ from that of non-rational animals. Rational creatures "alone [are] capable of the vision of God ...; for although other animals may know certain things that are true, nevertheless, man alone knows the nature itself of truth". ${ }^{51}$ This ability to know truth itself, ultimately to come to know God, is not something that human beings possess on their own but something they share in from truth itself as we have shown above. Aquinas says that the expression "the light of men" might also refer to God's own light, in this

\footnotetext{
${ }^{46}$ In Io., ch. 8, lect. 3, no. 1183, originally cited by Gilles Emery, O.P., who writes, "The creative causality of the Son is manifested by the rule of the causality of the primum: that which sovereignly possesses a perfection is the cause of that which has this perfection in a second way (by participation)", "Biblical Exegesis and the Speculative Doctrine of the Trinity in St. Thomas Aquinas's Commentary on John", 40.

${ }^{47}$ In Io., ch. 1, lect. 10, no. 207, "by [Christ's] essence he is the uncreated truth, which is eternal and not made, but is begotten of the Father; but all created truths were made through him, and these are certain participations and reflections of the first truth, which shines out in those souls who are holy" (emphasis added).

${ }^{48}$ In Io., ch. 1, lect. 1, no. 33, emphasis added.

${ }^{49}$ In Io., ch. 1, lect. 2, no. 97, "ipsa veritas quae manifestabilis est et manifestativa omnium". The capacity to know truth itself is present in all human beings and angels. As Aquinas will show in the rest of his commentary on John 1, the Incarnate Word, Jesus Christ, is the one who fulfills this capacity and even makes the Father known to us (John 1:18) in a way otherwise unknown to us and beyond our natural capacities.

${ }^{50}$ Aquinas holds that this participation in the Word as wisdom takes place through the Spirit when he comments on the verse "the Holy Spirit will teach you all things" (John 14:26): "Just as the effect of the mission of the Son was to lead us to the Father, so the effect of the mission of the Holy Spirit is to lead the faithful to the Son. Now the Son, once he is begotten Wisdom, is truth itself: 'I am the way, and the truth, and the life' (John 14:6). And so the effect of this kind of mission [i.e., of the Spirit] is to make us sharers (participes) in the divine wisdom and knowers of the truth. The Son, since he is the Word, gives teaching to us; but the Holy Spirit enables us to grasp it" (In Io., ch. 14, lect. 6, no. 1958).

${ }^{51}$ In Io., ch. 1, lect. 3, no. 101.
} 
case, "a light in which we participate". He continues, "we would never be able to look upon the Word and light itself except through a participation in it; and this participation is in man and is the superior part of our soul". ${ }^{52}$ The intelligence of the human being is nothing other than a sharing in the very intelligence of God. ${ }^{53}$ To summarize this creative presence of God, each creature's being shares in the divine being and each rational creature's wisdom shares in the divine wisdom. ${ }^{54}$ To be a rational creature is to be able to acknowledge our own lack of self-sufficiency: I am not my own being or my own wisdom, but I receive all of this from my Creator.

Alongside the uniqueness of the Word as God and of the participation in the Word appropriate to the rational creature, Aquinas also develops another level by which all creatures participate in the Word of God. Developing the affirmation that all things are created through the Word, Aquinas quotes Augustine's De Trinitate, "the Word is the art (ars) full of the living patterns (rationes) of all things". 55 This is a startling claim in many ways: all of creation, even inanimate creation, nonetheless has its origin in an intelligent and living pattern or ratio in the Word of God. Aquinas here goes so far as to employ the language of patterns or rationes of reality, the same language employed by Rohr. Moreover, Aquinas repeats the expression of the Word as the ars full of the living patterns of creatures at least two more times. ${ }^{56}$ Aquinas carefully explains his usage as follows,

the patterns (rationes) which exist spiritually in the wisdom of God, and through which things were made by the Word, are life, just as a chest made by an artisan is in itself neither alive nor life, yet the exemplar of the chest in the artisan's mind prior to the existence of the chest is in some sense living, insofar as it has an intellectual existence in the mind of the artisan. ... [Now] the

\footnotetext{
52 In Io., ch. 1, lect. 3, no. 101.

${ }^{53}$ See also, "For all men coming into this visible world are enlightened by the light of natural knowledge through participating in this true light, which is the source of all the light of natural knowledge participated in by men" (In Io., ch. 1, lect. 5, no. 129).

${ }^{54}$ Aquinas frequently repeats the theme of human wisdom as a participation in divine wisdom, "the minds of the wise are lucid by reason of a participation in that divine light and wisdom", (In Io., ch. 1, lect. 3, no. 103). Even those who are foolish and in darkness are not fully excluded from this participation in the divine wisdom, "whatever truth is known by anyone is due to a participation in that light which shines in the darkness; for every truth, no matter by whom it is spoken, comes from the Holy Spirit" (no. 103).

${ }_{55}$ In Io., ch. 1, lect. 2, no. 77, "Verbum est ars plena omnium rationum viventium". Aquinas's quote shortens Augustine's De Trinitate, 6.11: “....[O]ne perfect Word to which nothing is lacking, which is like the art of the almighty and wise God, full of all the living and unchanging ideas (ars quaedam omnipotentis atque sapientis dei plena omnium rationum uiuentium incommutabilium) which are one in it, as it is one from the one with whom it is one". Gerald Boersma has a helpful essay on Augustine's understanding of the way in which the Word of God is present in the patterns of creation, 'The Rationes Seminales in Augustine's Theology of Creation', in: Nova et Vetera, English Edition, vol. 18, no. 2 (2020): 413-441.

${ }^{56}$ See also In Io., ch. 1, lect. 2, no. 87, when Aquinas affirms, "the Word, who is the art of the Father, full of living patterns (rationes)". See also, "since the cause of all effects produced by God is a certain life and an art full of living patterns (rationes)" (no. 90).
} 
creature in God is the creating essence (creatura in Deo est creatrix essentia). Thus, if things are considered as they are in the Word, they are life. ${ }^{57}$

Non-living creatures may be said to possess life in God who is continually sharing his being with them as the Creator and knowing their forms to be through his Word. Participation allows Aquinas to speak of the living presence of the Word in inanimate creatures without falling into pantheism. The patterns or rationes of all creation have an existence in God in his one act of understanding; and they have another existence in created things as those created things participate in the pattern or ratio.

When Aquinas speaks of the divine ideas in the Summa Theologiae, he explains that these patterns are that by which creatures not only exist but that by which they share in varying likeness to the Creator. Participation illustrates a likeness of all creatures to God. Aquinas writes, "every creature has its own proper species, according to which it participates in some degree in likeness to the divine essence. So far, therefore, as God knows His essence as capable of such imitation by any creature, He knows it as the particular pattern (rationem) and idea of that creature". ${ }^{58}$ Participation thus makes possible imitation.

Aquinas articulates orders of existence that are not properly characterized as either dualistic or non-dualistic. Instead, they are participatory levels of sharing in the fullness of being, namely, the divine essence. Aquinas discerns a "fitting order (congruus ordo)" in the first verses of John and how it re-presents the story of creation: "in the natural order of things, existence is first; and the Evangelist implies this in his first statement, 'in the beginning was the Word' (John 1:1). Second, comes life; and this is mentioned next, 'in him was life.' Third comes understanding; and that is mentioned next; ' and the life was the light of men.'”59

\footnotetext{
${ }^{57}$ In Io., ch. 1, lect. 2, no. 91. The translation renders rationes as "archetypes", for which I have substituted "patterns".

${ }^{58}$ STh I, q. 15, a. 2. The translation at aquinas.cc renders rationem as "type", for which I have substituted "pattern". See Josef Pieper's commentary on and citation of this passage in "The Negative Element in the Philosophy of St. Thomas Aquinas", in The Silence of Saint Aquinas (South Bend, IN: St. Augustine's Press, reprinted 1999), 66. Pieper argues that Aquinas's understanding of truth depends upon his teaching of creation. Since things not only exist, but exist having been created, the truth of things depends on their fundamental correspondence to the divine mind whose knowledge itself creates things. Unlike the creative divine mind, the human mind thus receives the truth of things in a way that is non-creative. In other words, God's knowledge is the cause of created realities; created realities are the cause of human knowledge. Thus, Pieper writes, "The 'truth of things' [will be missed] unless we make it explicit that these things are creatura, that they have been brought into being by the creative knowledge of God". The result of this dependence of all things on God's creative knowledge has implications for how we interact with the world. Pieper continues, "it is the creative fashioning of things by God which makes it possible for them to be known by men" (55).

${ }^{59}$ In Io., ch. 1, lect. 3, no. 100. Aquinas says that "the light of men" (John 1:4) may also be interpreted as the order of grace: "the Evangelist considers here the restoration of the rational creature through Christ. ... [T] he Son of God assumed flesh and came into the world to illumine all men with grace and truth" (no. 104).
} 
In addition to the three levels in which creation participates in the Word, there is a redemptive participation of the rational creature in the Incarnate Word. ${ }^{60}$ Aquinas comments on "without me you can do nothing" (John 15:5):

For our works are either from the power of nature or from divine grace. If they are from the power of nature, then, since every action of nature is from the Word of God, no nature can act to do anything without him. If our works are from the power of grace, then, since he is the author of grace, because grace and truth came by Jesus Christ (John 1:17), then it is obvious that no meritorious work can be done without him. ${ }^{61}$

In all of our being and acting, we are dependent upon the perfect being and acting of the Word. And, yet, not in the same way. Aquinas distinguishes between created participation in the Word and graced participation in the same Word incarnate. After treating primarily the role of Christ as the divine Word in the first five verses of John, Aquinas turns in the remainder of the first chapter to consider the "the incarnation of the Word" and how Christ restores and illumines us in grace and truth. ${ }^{62}$

Aquinas employs the notion of participation to comment on the Gospel of John's presentation of John the Baptist and Jesus Christ. Aquinas observes that while both John and Jesus bear witness, they do so in different ways. According to Aquinas, Christ bears witness "as the existing light itself" whereas John "bears witness only as participating in that light". ${ }^{63}$ The difference between John and Jesus is neither dualistic nor non-dualistic. They are neither fully separate nor fully the same. Instead, John's participatory witness comes from - and depends upon - the fully-realized witness of Jesus Christ.

\footnotetext{
${ }^{60}$ Michael Waldstein distinguishes without separating the natural and graced levels of participation: "creatures are made after the exemplar of the eternal Son in his eternal procession. This exemplarity, which is fundamental in the natural order of creation, continues in the supernatural order of grace and divinization: created persons gain life by union with the Son, by participation in his sonship", see: "The Analogy of Mission and Obedience: A Central Point in the Relation between Theologia and Oikonomia in St. Thomas Aquinas's Commentary on John', in: Reading John with St. Thomas Aquinas, 92-112, 110.

${ }^{61}$ In Io., c. 15, lect. 1, no. 1993. Originally cited by David Burrell, C.S.C., 'Creation in St. Thomas's Super Evangelium S. Joannis Lectura', in: Reading John with St. Thomas Aquinas, 115-126, 125. Burrell describes the uniqueness of Aquinas's presentation of creation as "non-duality" since "creatures can never be separated from their creator" since they rely on the first cause for their very existence or esse (125). While I agree with Burrell that Aquinas's understanding of creation necessarily rejects any dualist accounts of God's relationship to the world, I find it more helpful to follow Aquinas's own language of participation rather than "non-duality". Participation maintains the hierarchical ordering of the Creation as the ever-present cause of creation as well as of the Incarnate Word as the ever-present cause of redemption. On Aquinas's interpretation of this passage as referring to the order of created nature as well as that of grace, see G. Mansini, O.S.B., '"Without Me You Can Do Nothing": St. Thomas with and without St. Augustine on John 15:5', in M. Dauphinas, B. David, and M. Levering (eds.), Aquinas the Augustinian (Washington, DC: The Catholic University of America Press, 2007), 159-180.

${ }^{62}$ In Io., ch. 1, lect. 4, no. 108.

${ }^{63}$ In Io., ch. 1, lect. 5, no. 117.
} 
In interpreting the role of John the Baptist's witness, Aquinas presents faith as a mode of participation in Jesus Christ. The Gospel narrates that the purpose of John's witness was "so that through him all men might believe" (Jn 1:7). For Aquinas, belief unites the believer to the object of faith. He presents belief as the graced participation in God's own light: "the salvation of man lies in participating in the light". ${ }^{64}$ Aquinas presents two stages to this participation, "first they would believe through faith, and later enjoy him through vision in heaven". ${ }^{65}$ Participation thus moves from imperfect to perfect. ${ }^{66}$

Faith is the beginning of a new manner of sharing in this divine life. Faith is when we cease prideful trust in the completeness of our vision of ourselves, of the world, and of God and begin to see reality as God sees, to know as God knows. Such language is not metaphorical since faith is nothing other than our higher-or more perfect-sharing in "the existing light itself" who is Jesus Christ. Aquinas describes this reality in the Summa Theologiae when he explains the way in which faith may truly be called a kind of knowledge: "faith ...does not proceed from the vision of the believer, but from the vision of Him who is believed". ${ }^{67}$ Faith is a second-hand-or participatory - knowledge by which we believe what Christ sees. ${ }^{68}$ In his Commentary on John, Aquinas puts it simply, "the Son of God is light by his very essence; but John and all the saints are light by participation". ${ }^{69}$ By grace and by faith, the rational creature participates in the Word incarnate. Aquinas comments on "He was the true light" (John 1:9) and writes, "the Word of God was not a false light, nor a symbolic light, nor a participated light, but the true light, i.e., light by his essence". ${ }^{70}$ Aquinas thus rejects Arius, who held that, "Christ was not true God, but God by participation". ${ }^{71}$ Aquinas affirms that Jesus Christ has a fully created human nature but should not be called a creature since that would imply the Arian position. ${ }^{72}$ Jesus Christ is the eternal Word now incarnate.

Jesus' uniqueness as the Word incarnate allows other human beings to share in his divine light, his divine truth, his divine love. When seen through the lens of participation, Jesus' uniqueness creates communion. Because Christ enjoys the divine presence in a manner unlike us, we become able to enjoy the divine presence in a manner like his. Earlier we observed that the living patterns or rationes of created

${ }^{64}$ In Io., ch. 1, lect. 5, no. 122.

${ }^{65}$ In Io., ch. 1, lect. 5, no. 120.

${ }^{66}$ In Io., ch. 1, lect. 5, no. 120.

${ }^{67}$ STh I, q. 12, a. 13, ad 3.

${ }^{68}$ Aquinas teaches that we come to know the saving truth about God through the Word as incarnate: "As to nature (secundam naturam), in Christian doctrine the beginning and principle of our wisdom is Christ, inasmuch as he is the wisdom and Word of God, i.e., in his divinity. But as to ourselves (quoad nos), the beginning is Christ himself inasmuch as the Word has become flesh (John 1:14), i.e., by his incarnation" (In Io., ch. 1, lect. 1 , no. 34 ).

${ }^{69}$ In Io., ch. 1, lect. 4, no. 123.

${ }^{70}$ In Io., ch. 1, lect. 5, no. 125.

${ }^{71}$ In Io., ch. 1 , lect. 5, no. 126.

72 STh III, q. 16 , a. 8. 
things exist in the divine Word as well as in created realities. The difference in the Word's unique perfection of existence does not separate creatures from the Word but allows creatures to participate in the Word's existence and even his understanding or ars as Augustine and Aquinas describe. In fact, these participatory patterns are what allows creatures to imitate the Creator. Beyond these modes of imitation, there are more perfect modes of imitation made possible through the Incarnation. The uniqueness of Christ as the perfect light itself is what allows the faithful in this life and the saints in heaven to share in this divinizing light. ${ }^{73}$

Nonetheless, Aquinas ever attends to the difference between God's creative and incarnate presence. Aquinas finds this distinction between creation and incarnation when the Gospel affirms that "he was in the world" (Jn 1:10) and then that "he came in to the world" (Jn 1:11). To affirm that God was "in the world" requires us to distinguish God's being from creaturely being: God is "neither localized nor a part of the universe". ${ }^{74}$ Turning this imagery upside down, Aquinas says that "the entire universe is in a certain sense a part, since it participates in a partial way in his goodness". The relationship between God and creation is an asymmetrical relation. God's presence in things ought not to be imagined as another creaturely mode of presence that would be in competition with the creature's own existence. Instead, Aquinas says that God "acts by creating .... [and] by acting gives existence". ${ }^{75}$ Aquinas summarizes this by affirming that "God is in all things by his essence, presence, and power". ${ }^{76}$ That "he came into the world" announces that the one who assumed a full human nature was also the one who is continually creating the world. Aquinas eloquently juxtaposes these two modes of presence, the presence of the Creator Word and the presence of the Incarnate Word: "the Son of God came into the world and yet was in the world. For he was there, indeed, by his essence, power, and presence, but he came by assuming flesh. He was there invisibly, and he came in order to be visible". ${ }^{77}$ Aquinas here emphasizes the dissimilarity of God's presence in Jesus Christ from his presence in creation. Creation is not a larger category of Incarnation of which Jesus Christ is a particular instance, perhaps even the highest instance. Yet, neither would it be true to see creation and Incarnation as opposed to one another. Aquinas portrays a harmony between these two modes of divine presence since the

\footnotetext{
${ }^{73}$ Aquinas describes being elevated by the light of glory as a kind of deiformity in Summa Theologiae I, q. 12., a. 5, "By this light the blessed are made deiform-i.e., like to God, according to the saying: 'When He shall appear we shall be like to Him, and we shall see Him as He is' (1 John 3:2)".

${ }^{74}$ In Io., ch. 1, lect. 5, no. 133.

${ }^{75}$ In Io., ch. 1, lect. 5, no. 133.

${ }^{76}$ In Io., ch. 1, lect. 5, no. 134. This expression is familiar to readers of the Summa Theologiae: "God is in all things by His power, inasmuch as all things are subject to His power; He is by His presence in all things, as all things are bare and open to His eyes; He is in all things by His essence, inasmuch as He is present to all as the cause of their being [causa essendi]" (I q. 8, a. 3).

${ }_{77}$ In Io., ch. 1, lect. 5, no. 144. See STh, I, q. 43, a. 1, in which Aquinas presents the visible mission of the Son, i.e., the Incarnation, "as meaning a new way of existing in another; thus the Son is said to be sent by the Father into the world, inasmuch as He began to exist visibly in the world by taking our nature".
} 
Word who is already present in creation is now present in creation through the Incarnation in a singular manner.

The newness of the Incarnation reshapes rational creatures in its image. The unique sonship of Christ is not kept to himself but is shared with others. Following the narrative on John, Aquinas turns to the verse "he gave them power to become children of God" (Jn 1:12). He emphasizes the way in which the Incarnation is the ever-present cause of our newness. Aquinas writes, "the coming of the Son of God is great, because by it we are made sons of God" quoting Galatians 4:4-5 in support. He praises the fittingness that "we, who are sons of God by the fact that we are made like the Son (assimilamur Filio), should be reformed through the Son (reformemur per Filium $) "{ }^{78}$ As we saw earlier, participation is the ground of likeness and imitation. So our reformation is accomplished through the Son as we are assimilated to the Son, made like unto him. Here we are deeply united with the unique sonship of Jesus Christ. Aquinas articulates three ways in which human beings become sons of God, "through sanctifying grace, through the perfection of their actions, and through the attainment of glory". ${ }^{79}$ To be children of God sets the human creature on a path that begins now but ends in a communion beyond that which is capable in this present mode of earthly existence.

As we have previously observed in Aquinas's exposition of John, this new participation in Christ is made possible because of the uniqueness of Christ in comparison with the rest of humanity. He alone is the natural Son of God; the rest of us are adoptive sons. He enjoys a divine presence that is both like and unlike ours. Aquinas traces carefully the grammar of "children of God ... who are born, not of blood, nor of the will of the flesh, nor of the will of man, but of God (ex Deo)" (Jn 1:13) to emphasize the distinction:

since only the Son of God, who is the Word, is of the substance of the Father and indeed is one substance with the Father, while the saints, who are adopted sons, are not of his substance, the Evangelist uses the preposition 'out of $(e x)^{\prime}$ saying of others that they are born of God (ex Deo), but of the natural Son, he says that he is born of the Father (de Patre). ${ }^{80}$

Adoptive sons and daughters are ex Deo; the natural son is de Patre. Aquinas notes the way that Scripture speaks of Christ both as the "only-begotten" (Jn 1:18) and as the "first-born" (Rom 8:29) and explains the possible contradiction in this same way. Christ alone is a natural son, so "only-begotten", and yet this natural sonship is the source of others to receive sonship, so "first-born". ${ }^{81}$ Our adoptive sonship

\footnotetext{
${ }^{78}$ In Io., ch. 1, lect. 6, no. 149.

${ }^{79}$ In Io., ch. 1, lect. 6, no. 156.

${ }^{80}$ In Io., ch. 1, lect. 6, no. 162.

${ }^{81}$ Aquinas writes, "Christ is called the only-begotten of God by nature; but he is called the first-born insofar as from his natural sonship, by means of a certain likeness and participation, a sonship is granted to many", (In Io., ch. 1, lect. 7, no. 187).
} 
participates in his natural sonship. Aquinas thus avoids a dualistic separation between Jesus Christ and us as well as a non-dualistic identification between Jesus Christ and us.

Aquinas further addresses the uniqueness of the presence of God in Jesus Christ when he comments on "the Word was made flesh, and dwelt among us" (Jn 1:14). That "flesh" here indicates a fully human nature, body and soul, requires an understanding of the fruit and purpose of the incarnation. Aquinas writes, "the Word assumed human nature in order to repair it. Therefore, he repaired what he assumed". ${ }^{82}$ The Word's unique personal union with our common human nature is the path of savlation. Aquinas highlights the distinctive language of "the Word was made flesh" to argue that Christ is not merely a prophet. Because Christ possesses the unity of person rather than a prophetic indwelling of the divine person alongside the human person (or supposite), this allows us to affirm that God became man and that man became God, even so far as to say that God is man. ${ }^{83}$

When Aquinas comments the second-half of John 1:14, "and dwelt among us", he identifies diverse levels of how God dwells in his creation through the idea of participation. Aquinas identifies the confusion of modes of indwelling as the heresy of Nestorius, who held that there were two natures and two persons in Jesus Christ. Aquinas explains,

Nestorius misunderstood this phrase ['and dwelt among us'] and said that the Son of God was united to man in such a way that there was not one person of God and of man. For he held that the Word was united to human nature only by an indwelling through grace. From this, however, it follows that the Son of God is not man. ${ }^{84}$

Instead of the graced indwelling proper to the saints, in Christ there is the personal union by which the Word assumes a human nature that now subsists in the Person of the Word. Aquinas goes on to interpret the meaning of the verse by affirming the unity of the Person while maintaining the distinction of the divine and human natures: "the Word dwelt in our nature; therefore, he is distinct in nature from it. And so, inasmuch as human nature was distinct from the nature of the Word in

\footnotetext{
${ }^{82}$ In Io., ch. 1, lect. 7, no. 168. The word "reparo" here translated as repair may also be restore, renew, make good, refresh, revive (Roy J. Deferrari, A Latin-English Dictionary of St. Thomas Aquinas).

83 "And so the Evangelist expressly said 'was made,' and not assumed, to show that the union of the Word to flesh is not such as was the lifting up of the prophets, who were not taken up into a unity of person, but for the prophetic act. This union is such as would truly make God man and man God, i.e., that God would be man", (In Io. ch. 1, lect. 7, no. 170.) Aquinas rejects the one-person two-supposite Christology allowed for in Peter Lombard's Sentences on the basis that "According to this opinion the proposition, that God was made man and man was made God, is not true" (In Io., ch. 1, lect. 7, no. 171). Aquinas treats the importance of maintaining certain grammatical and propositional formulations about Christology in the Summa Theologiae III q. 16, aa. 1-2, for example, that "God is man [Deus est homo]" and "man is God" in the case of Jesus Christ. ${ }^{84}$ In Io., ch. 1, lect. 7, no. 174.
} 
Christ, the former is called the dwelling place and temple of the divinity". ${ }^{85}$ The assumption of the human nature to the divine Person of the Word means that the Word dwells in the human nature of Christ in the very unity of the Person. This allows Aquinas to affirm the reality of the Incarnation against Nestorius and to confess that the "Son of God is man". In the case of the saints, however, the Word dwells in them "through grace" so that their personal identity remains albeit now enlivened by the Word. ${ }^{86}$ The personal indwelling of the Word in Christ's human nature causes the graced indwelling of the Word in the saints. ${ }^{87}$

When Aquinas turns to the earthly life of Jesus, he presents Jesus Christ as the unique and efficacious revelation of God. Contra Rohr, Jesus does not merely give witness to the patterns already present in creation, patterns of the universal Christ. Were this the case, Jesus would merely exemplify what we was already available to human reason. Instead, Aquinas presents Christ as the definitive cause and teacher of our salvation. When Aquinas comments on John 1:16, "of his fullness we have all received", he distinguishes between the fullness of the divine presence in Mary and the saints and that of Jesus Christ. Christ's fullness not only perfects his human nature but also is the cause of the perfection of the saints. ${ }^{88}$ Aquinas describes "a fullness of efficiency and overflow, which belongs only to the man Christ as the author of grace". ${ }^{89}$ As the author of grace, Christ possesses fully what he shares with others. This is essential to the understanding of participation: the fullness of reality causes others to share in that fullness. Aquinas explains further, "For Christ received all the gifts of the Holy Spirit without measure, according to a perfect fullness; but we participate, through him, of some portion of his fullness; and this is according to the measure which God grants to each". ${ }^{90}$ The Holy Spirit is given fully to the human nature of Jesus Christ. ${ }^{91}$ Thus when we participate in Christ, we receive from Christ the same Holy Spirit that his human nature received as united to the person of the

\footnotetext{
${ }^{85}$ In Io., ch. 1, lect. 7, no. 173.

86 See Daniel Keating who uses participation to show what divine indwelling does and does not entail: "Christian life as an existence in the Trinity does not remove us from the sphere of being and remaining creatures. ... Ours is a 'participation' in the divine nature, but this participation is dependent on the utter difference between Creator and creature remaining intact", 'Trinity and Salvation: Christian Life as an Existence in the Trinity,' in: G. Emery, M. Levering (eds.), The Oxford Handbook of the Trinity (New York: Oxford University Press, 2011), 442-453, 452.

${ }^{87}$ See STh III, q. 59, a. 2, ad 2: "It belongs to God alone to bestow beatitude upon souls by a participation with Himself; but it is Christ's prerogative to bring them to such beatitude..."

${ }^{88}$ In Io., ch. 1, lect. 10, no. 202, "the fullness of grace in Christ is the cause of all graces that are in intellectual creatures".

${ }^{89}$ In Io., ch. 1, lect. 10, no. 201.

${ }^{90}$ In Io., ch. 1, lect. 10, no. 202, emphasis added.

${ }^{91}$ Dominic Legge, O.P., writes: "Christ is greater than every other prophet; possessing the fullness of the Holy Spirit, Christ's prophetic knowledge surpasses that of all others", in The Trinitarian Christology of Thomas Aquinas, (New York: Oxford University Press, 2017), 184. Legge presents the perfection of Christ's human knowledge as dependent upon the invisible mission of the Holy Spirit (172-86).
} 
Son. Jesus' uniqueness does not separate him from the rest of us but rather makes possible our communion in him.

When Aquinas comments on John 1:18, "No man has ever seen God: the only begotten Son, who is in the bosom of the Father, has made him known", he titles his lecture simply "the revelation of the Son" and presents the Son's revelation as a form of teaching (doctrina). ${ }^{92}$ Aquinas draws three conclusions from this verse: first, we need this teaching; second, the Son is uniquely able to offer it; and, third, that the teaching itself makes God the Father known. ${ }^{93}$ We do not currently see God properly because of ignorance and errors arising from our broken human experience as well as the inability to see God as he is in this earthly life. Christ, however, sees God properly since the Son is fully like the Father as a natural son, the only natural son, consubstantial with the Father. Aquinas describes Christ as "the competent (sufficiens) teacher" of this necessary wisdom of the truth about God. ${ }^{94}$ The perfect vision of the divine Son allows the created soul of Jesus Christ to know God truly without knowing him as the divine nature knows itself him. ${ }^{95}$

Aquinas shows a continuity and discontinuity between the prophets and Christ by means of participation. The eternal Word spoke through the prophets and now speaks as Jesus Christ. Whereas the prophets made God known "to the extent that they shared (particeps) in the eternal Word", the teaching of Christ "surpasses all other teachings in dignity, authority and usefulness, because it was handed on immediately by the only begotten Son, who is the first wisdom". ${ }^{96}$ The Son teaches through the prophets; in Jesus Christ, the Son himself teaches immediately. The Son is the first wisdom as the creative divine Word who now also subsists in a human nature. As such, the Son's identity as the Son of the Father is what he teaches and thus makes the Father known. In each of these ways, Christ's teaching is always to be shared. The reality of the Incarnation allows first wisdom itself to hand on himself "immediately" to the human race. ${ }^{97}$ His unique existence as the Word of God incarnate allows him to communicate to others a new and distinctive mode of participation in God.

\footnotetext{
${ }^{92}$ For a consideration of Aquinas's treatment of the teaching of Christ and revelation, see my 'The Role of Christ and the History of Salvation in Aquinas's Theology of Revelation', in: Angelicum, Vol. 96, No. 3 (2019): 293-328.

${ }^{93}$ In Io., ch. 1, lect. 11, no. 208.

${ }^{94}$ In Io., ch. 1, lect. 11, no. 215.

95 In Io., ch. 1, lect. 11, no. 219.

${ }^{96}$ In Io., ch. 1, lect. 11, no. 221.

${ }^{97}$ Aquinas holds that Christ's teaches through the teaching of his apostles and disciples: "most of all he wanted to teach his disciples, who were destined to be the teachers of the entire world" (In Io., ch. 6, lect. 1, no. 864). Michael Sherwin, O.P, helps us to see how Christ immediately teaches through the mediation of his disciples: in his divinity, Christ "is the first cause of all learning ... and able to employ his creatures as instruments and secondary causes of his teaching. They thus become teachers by participation and truly merit the title magistri", 'Christ the Teacher in St. Thomas's Commentary on the Gospel of John', in: Reading John with St. Thomas, 173-193, 184.
} 


\section{Conclusion}

Rohr presents the message of the universal Christ as a recovery of the ubiquity of the divine presence and criticizes the Christian tradition's emphasis on the unique mode of divine presence in the incarnation. ${ }^{98}$ Such a Christology both rightly affirms the divine presence in all creation and sees this as the ground of the incarnation and incorrectly reduces the presence of God in the incarnation-as well as in the sacraments or in charity - to that presence already in creation. To accomplish this project, Rohr separates the universal Christ from the historical Jesus. The historical Jesus now unveils universal patterns of creation, patterns of the universal Christ's presence in all created things. According to Rohr, we need to turn from a dualistic focus on God present in Jesus and the Church to a non-dualistic vision of the universal Christ present in all creation. In short, we need to turn from-or perhaps with - the historical Jesus to the universal Christ. According to Rohr, to focus on Jesus as the unique and personal Incarnation - as affirmed in the Catholic creeds - separates God from creation and Jesus from us.

Rohr's reinterpretation of creation as incarnation comes with a cost and collapses reality into a pantheistic Christology. In Rohr's presentation, the incarnation is no longer a presence by union distinct from a presence by grace in those joined to God. The graced reality of charity and faith likewise are no longer a presence by grace distinct from the manner in which God is present in all creation. ${ }^{99}$ Rather than seeing how the incarnation of the Word changes everything, Rohr empties the incarnation of the Word in Jesus Christ of any specific meaning or efficacy. Rohr rejects a dualistic view that separates the Creator from the creation and adopts a non-dualistic view makes creation to be divine. Rohr likewise rejects a dualistic view that separates Incarnation from creation but adopts a non-dualistic view makes creation to be an incarnation. Even God appears as merely another mode of the created order albeit the highest and most spiritual aspect of creation. By trying to see everything as incarnation, Rohr ends up simply presenting everything as creation or, to press the point more forcefully, creation as everything.

Aquinas's participatory Christology offers a more satisfying and more faithful alternative to Rohr's pantheistic Christology. Aquinas articulates God's various presences via participation rather than a flattened view arising from the contrast of dualism versus non-dualism. The doctrine of participation distinguishes between God's perfect existence as the Creator and the participated existence of all created realities, which receive their existence from God. The created realities we encounter thus are discovered to be neither separate from nor identified with God but distinct

\footnotetext{
98 Rohr includes the following epigram at the beginning of his book, "The only really absolute mysteries in Christianity are the self-communication of God in the depths of existence-which we call grace, and in history - which we call Christ. -Fr. Karl Rahner, Jesuit priest and theologian, 1904-1984".

99 Rohr dedicates his book to his beloved dog, Venus, and writes, "Without any apology, lightweight theology, or fear of heresy, I can appropriately say that Venus was also Christ for me".
} 
from God. Participation articulates the way in which all creation receives its being and operation from the perfection of the Word and all rational creation receives its active understanding from the perfection of the Word. Moreover, participation expresses the way in which the children of God receive their higher participation in the divine nature from the personal union of the human nature of Jesus to the divine Word. ${ }^{100}$

As we have seen, Aquinas distinguishes among various levels of God's presence as he interprets the prologue of John. ${ }^{101}$ God himself is being itself, the sheer fullness of actuality, who creates the cosmos. The divine nature exists as the Father eternally expressing his Word (or begetting eternally his Son) in his Spirit. All of creation and of the re-creation that comes through redemption come to be through the Word. Whatever exists at all receives its partial existence from the fullness of divine existence and so imitates the divine Word's creative patterns or rationes, the living art (ars) of the Father. Whatever exists in the manner of a rational creature receives its partial rationality from the fullness of rationality in the divine existence and in the divine Word and so may come to discern the Creator, who is truth itself. In the incarnation, the humanity of Jesus Christ is the perfected humanity conjoined fully to the natural sonship of the divine Word. Whatever exists as a rational creature in the communion of sonship through grace thus receives its partial sonship from the fullness of sonship present in the incarnate Word. Further, whatever exists in the perfected communion of sonship in glory exists in and from this same incarnate Word. All of these distinct modes of divine presence are what is meant by the reference to a participatory Christology.

The reality of the Incarnation is necessarily a story about distinctions among God's modes of presence. God is present in himself as the Creator in a way distinct from his presence in creation. This allows human beings to be freed from idolatrous attempts at trying to find God incorrectly in created things and so turn to the living

\footnotetext{
${ }^{100}$ See 2 Peter 1:4, "sharers of the divine nature".

${ }^{101}$ In his Commentary on the Sentences, Aquinas offers a concise summary of three distinct modes by which God is present in creation: "Now a creature may be united to God in three ways. First, by way of likeness (similitudinem) only, insofar as in a creature is found some likeness to the divine goodness, but not that it reaches to God according to its substance; and this union is found in all creatures as a likenesses to the divine goodness. As such, this is a common mode by which God is in all creatures by essence, presence, and power (per essentiam, praesentiam et potentiam). Second, a creature may reach to God himself with respect to its substance, and not only by likeness; and this is by way of activity (operationem). This occurs when anyone adheres to first truth itself by faith and to the highest good itself by charity. As such, this is another mode by which God is particularly in the saints by grace (per gratiam). Third, a creature attains to God himself not only according to activity but also according to being (esse): not, indeed, as its being is the act of essence, because a creature is not able to cross over into the divine nature; but inasmuch as it is the act of the hypostasis or the person, to whose union the creature has been assumed: and thus we have the final way by which God is in Christ by way of union (per unionem)" (In I Sent., dist. 37, q. 1, a. 2. I am indebted to Fr. Gilles Emery, O.P. for this reference. The translation is mine.) As we have seen in the Commentary on John and the Summa Theologiae, Aquinas continually refers to an additional mode of God's presence in creation in the rational nature. See, for example, STh I, q. 93, a. 4 and the distinct between the image of creation and that of re-creation.
} 
God as the Creator. God is present in Jesus Christ as the Word made flesh in a way that is unique from his presence in other rational creatures. This is what allows human beings to be healed from isolation and wounds and elevated to a sharing in God's eternal communion. These very distinctions are undermined by the attempt to reinterpret the creation as incarnation. We can avoid the deformities caused by dualistic thinking better by following Aquinas's teaching on participation. The Creator is not separate from the creature but is the creature's constant source and cause. The Incarnation is not separate from the reborn creature but is the reborn creature's constant source and cause. The distinctions between Creator and creature and between Incarnation and creation are what allow salvation and genuine healing from our wounds to take place.

The uniqueness of the divine Word Incarnate allows the rational creature to be reformed and healed so that we may live as children of God by grace and faith in this life and by glory and vision in the next. This definitive reality of the Incarnation includes all of the earthly mysteries from the first moment of the Incarnation up to and including the ascension to the right hand of the Father and his eventual return to render justice to the living and the dead. The Incarnation is not the same as the presence of the Word in all rational creatures even in those united to God by faith and love. Instead, Jesus' human nature exists in the personal union of the Word. This personal union of human nature with the divine Son of God allows Aquinas to confess the truth of the Incarnation, namely, that "the Son of God is man". The historical Jesus thus does not merely witness to the universal Christ as does John the Baptist. No, the human nature of Jesus witnesses to his own divine identity as the Son of God who came from the Father. Because the Son of God is man according to the personal union, the rest of humanity may let ourselves be taught by Christ the teacher. When we learn from the Incarnate Christ we thus participate not merely in the Word's patterns or rationes displayed in all creation but in the Word's eternal filial relationship to the Father. Aquinas thus helps us to see that the incarnation is much more than creation. The incarnation not only renews creation but elevates creation to participate in God's eternal life. Rather than presenting creation as the incarnation, Aquinas presents "Christ, who as man, is our way to God". ${ }^{102}$ Aquinas's participatory Christology thus allows one to save the helpful reminder the divine Word may be encountered in all created things while safeguarding the saving and healing efficacy of encountering that same Word incarnate in Jesus Christ.

102 STh I, q. 2, prologue, "Christo, qui, secundum quod homo, via est nobis tendendi in Deum". 